\title{
Editorial
}

\section{Under the dappled light: glimpsing leadership through the humanities}

This, the second issue of Leadership and the Humanities, offers a whirlwind tour through the humanities today, from humor to ethics, from faith to fiction, from history to art. Notwithstanding the popularity, utility, and virtues of the social-scientific paradigm that looms over the field of leadership studies today, our authors, taken together, point in a different direction: they suggest that leadership can be profitably approached, and indeed ultimately best understood, from a humanistic - a human - perspective. To truly explore leadership, our colleagues jointly assert in the following pages that one must not merely wrestle with hypotheses, data, and statistical correlations, but must also be sensitive to the power of a prayer, a painting - or a pun - and their power to weave or tear the sensitive web of relations among individuals: the flow of messages, images, perceptions, motives, doubts, fears, and leaps of faith that comprise the vital, irreducible human context in which leadership happens.

Art's depiction of - and sometimes confrontation with - leadership is the topic that Nicholas Warner explores first in this issue. Warner explains that his aim is not to 'trawl' individual works of art for 'nugget-like' lessons on how or how not to lead, but to encourage 'a deeper understanding of leadership as a complex ethical, historical, and cultural phenomenon, with an equally complex relationship to the construction and manipulation of images.' Beginning with Antoine-Jean Gros's monumental 1804 painting of Napoleon magnanimously extending his bare hand to a victim of bubonic plague at Jaffa, Egypt, Warner explores the power of images to glorify - or to subvert - their subjects. The paining depicts a historical event, as Warner informs us, at least in bare fact: Napoleon did visit a hospital of his sick and plague-ridden soldiers during the Egyptian campaign. But overlaid on the image itself, Warner argues, is the knowledge viewers bring to it: Napoleon was eventually forced to abandon Egypt, speeding his retreat by executing prisoners and even, it was widely believed, poisoning some of his own sick soldiers. Thus an image meant ostensibly to aggrandize its subject (the painting was executed in the year Napoleon declared himself emperor) can be read and has been read by many - as a mocking send-up of Napoleon's 'toxic leadership.' This kind of complex negotiation between the artist, the subject, and the viewer is for Warner part of the value of bringing art into leadership studies; the complexities of this three-cornered relationship to capture the significance and import of images mirrors the struggle for images, representation, and meaning that takes place between leaders and followers.

In the second paper, Thomas Cronin encourages us to laugh at politicians. Or, rather, he notes how persistent across culture and history has been the human tendency to laugh at the powerful. As far back as Aristophanes, he reminds us, humor and satire have been tools of the many or the weak against the few or the mighty: a safety valve to release pressure, or a way to express the deep ambivalence all human beings seem to feel 
about those who possess the power and authority of leadership. Cronin quotes the great American humorist, Will Rogers, expressing this ambivalence in a line about his congressman: 'I'm torn between local pride and fear for the nation.' 'Shared laughter,' Cronin tells us, 'contributes to group cohesion and can often reduce the distance between leader and led.' Quoting the scholar Manfred deVries, he notes that humor 'can be a formidable weapon against those who ... refuse to recognize or accept the truth.'

Yet truth itself may be challenged as 'the' foundation of leadership. That is the insight of Emmanuel Levinas, the Lithuanian/French philosopher sensitively explored by Jen Jones in this issue. For Levinas, the search for truth cannot take priority over the responsibility - the ethical responsibility - that an individual has for others or, as Levinas would term it, the Other. Jones shows how Levinas's approach is deeply relevant for leaders and for those who study leadership, for Levinas seeks to reorient the philosophical project away from a self-oriented, even self-obsessed search for 'truth' as a kind of object, to an ethical engagement with and acceptance of others: 'ethics as first philosophy,' in Levinas's famous phrase. Jones points out that this is not merely an altruistic argument for a particular kind of leadership or leadership ethics; rather, Levinas teaches that one can only truly learn (and thus lead) by empathetic engagement and 'encounter' with the Other. 'Others,' as Jones puts it, 'provide understanding for leaders to learn what they could not know otherwise.' Against the many unifying, even totalizing forces that commonly drive leadership in our world - efforts to create uniform and consistent identities and communities bound together with a single vision, a single morality, a single culture - Levinas, as Jones shows, calls for a different understanding of the leadership endeavor: ultimately, a leadership that respects the permanent difference of an Other that 'maintains alterity and can never be fully understood.' With so much of the leadership tradition emphasizing unity, identity, and integration of selves, Levinas provides a radically different understanding - and one that, as Jones recognizes, may be particularly pertinent for the new challenges of leadership in the diverse world of the twenty-first century.

Today, at least in the west, no 'Other' provokes more anxiety than Islam, and no Islamic thinker appears more threatening to modernity than Sayyid Qutb, the intellectual father of the Muslim Brotherhood and modern 'radical' or politically active Islam. In his contribution to this issue, Mark Menaldo explores the life and thought of Qutb (19061966), in particular his redefinition of the concept of jahiliyyah - and the implications of his influence for the Islamic world's interactions with its own 'Other', the west. Qutb, as Menaldo shows, was complex: an Egyptian steeped in traditional Quranic education, with a youthful taste for literature, poetry, and secular thought. In his forties, Qutb spent 2 years (1948 to 1950) traveling across the United States to study American education. This proved to be a critical phase in his development as a thinker. As he saw and experienced American education and culture, he became increasingly alienated, rejecting the American model as a gaudy, decadent materialism obscuring a darker reality of racism, sexual profligacy (and dangerous female manipulation of sexuality: Menaldo quotes Qutb on American women's dangerous deployment of the power of 'the round breasts, the full buttocks, the shapely thighs'), and aggressive, omnipresent violence: America was, in Qutb's mind, says Menaldo, a 'set of fractured systems.' In Qutb's final decade, even while he was imprisoned and tortured, and until he was executed in 1966, Qutb worked to develop his unique, complex perspective on Islam, simultaneously conservative and backward-looking, and radical and earth-shaking. Specifically, Menaldo says, Qutb 'reinterpreted' the Qu'ran and recast the old concept of jahiliyyah, wrenching it out of its historical context (it traditionally denoted the Arab 'age of ignorance' before the coming of Muhammad) to become a recurring challenge facing 
Muslims throughout history, 'in which Islam is threatened by ignorance and barbarism.' With this conception of a civilizational struggle for survival as a starting point, Qutb laid down a challenge to the faithful: to defend their faith might require going on the offensive: a conception of jihad, in Menaldo's phrasing, as a 'universal movement that strives to replace jahili (un-Islamic) societies with a universal Islamic system.' The story of Qutb's legacy continues to be written, all too often in blood.

Rounding out this issue are reviews of two remarkable recent books on leadership: Simon Robinson reviews John Rayment and Jonathan Smith's study of 'misleadership' - leadership that fails because it is missing, misguided, misinformed, or Machiavellian. Robinson, while praising the book, suggests that the 'Machiavellian' leader is worth a second thought, as Machiavelli's famous 'ends justify the means' dictum may gain a measure of merit or at least seriousness if we keep in mind that the ends need not be the narrow personal ends of the leader, but the very goals, aspirations, and imperatives of the group or community the leader has charge of. Such a view certainly would complicate what it means to lead, and to mislead. Our final review is Rita Gardiner's thoughtful take on the collection of essays edited by Jonathan Gosling and Peter Villiers on 'fictional leaders.' Fiction, Gosling, Villiers, and their authors argue, has much to teach us about leadership - but the act of reading, and reflecting on fiction and other art, also has much to teach us about how we ourselves are implicated in the phenomena of leadership. No 'great men' here - rather, in the pages of this book, as in the pages of this issue of Leadership and the Humanities, there are serious explorations of the difficult negotiations, claims, counter-claims, and commitments of those who come together under the dappled light of leadership to live, to strive, to create, to clash, to question, to wonder.

Michael Harvey 